\title{
Toxic Heavy Metals in the Mahul Creek Water of Mumbai, India
}

\author{
Pravin U. Singare ${ }^{1, *}$, M. V. A. Ansari ${ }^{1}$, N. N. Dixit $^{2}$ \\ 1 Department of Chemistry, Bhavan's College, Munshi Nagar, Andheri (West), \\ Mumbai - 400058, India \\ ${ }^{2}$ Department of Chemistry, Maharashtra College, Jahangir Boman Behram Marg, Nagpada, \\ Mumbai - 400008, India \\ *E-mail address: pravinsingare@gmail.com
}

\begin{abstract}
The present study was performed for the period of one year from January 2013 to December 2013 in order to understand the level of toxic heavy metals in the water of Mahul Creek near Mumbai. It was observed that the annual average concentration of heavy metals like $\mathrm{Cd}, \mathrm{As}, \mathrm{Hg}, \mathrm{Cr}, \mathrm{Pb}, \mathrm{Cu}, \mathrm{Ni}$ and $Z n$, was found to be $0.003,0.004,0.0009,0.012,0.015,0.019,0.04$ and $0.23 \mathrm{ppm}$ respectively. The results suggest that there is a need to have such scientific monitoring for longer time period in order to understand the trend in level of these toxic heavy metals discharged in to the creek water. It is feared that the existing problem if ignored may increase the level of this heavy metals in creek water thereby creating threat to the biological life of an aquatic ecosystem. From the results of the present investigation it seems that the time has come to move towards ecosystem specific discharge standards to maintain the health and productivity of natural resources on which the majority of Indians are dependent.
\end{abstract}

Keywords: industrial effluents; heavy metals; toxic metals; creek water; Mahul Creek; Mumbai

\section{INTRODUCTION}

In India, during the past few years, attempts were made to develop strategies directed towards more integrated approach in coastal environments [1]. Since most of the Indian industries are situated along the banks of river and creek for easy availability of water and also disposal of the wastes. It is found that one-third of the total water pollution in India comes in the form of industrial effluent discharge, solid wastes and other hazardous wastes [2-17]. Previous data on water pollution along creeks [18-25] points out to the need of systematic and regular monitoring of pollution level for further improvement in the industrial waste water treatment methods. Environmental problems concerning coastal and aquatic bodies cannot be addressed in isolation. They are intricately interwoven with each other. The environments of land and creek are interdependent, linked by complex atmospheric, geological, physical, chemical and biological interactions. Today it is realized that solution to environmental problem can only be achieved through comprehensive, systematic and sustained approach. According to one study it is estimated that Mumbai city of India itself discharges around 2200 MLD of waste to the coastal waters [26]. Among the different pollutants entering the water bodies, heavy metals are of great concern. These toxic heavy 
metals entering the aquatic ecosystem may lead to geoaccumulation, bioaccumulation and biomagnifications; further they may also enter the food chain [27,28]. Food chain contamination by heavy metals has become a burning issue in recent years because of their potential accumulation in bio-systems through contaminated water [29-33]. In view of day by day increasing pollution issues related to the water bodies in Mumbai, city of India, we have initiated the study to understand the level of toxic heavy metals in the water samples collected along the Mahul Creek of Mumbai. Since the present study area receives heavy pollution load from the surrounding refineries, agrochemical and other industries and also domestic effluent from the surrounding slum areas, it is expected that the results of our study will provide information regarding trend in heavy metal pollution load entering the creek.

\section{EXPERIMENTAL}

\section{1. Study Area}

Mahul creek $\left(19^{\circ} 01^{\prime} \mathrm{N} \& 72^{\circ} 53^{\prime} \mathrm{E}\right)$ lying on the east coast of Mumbai along the Arabian sea, is situated in Chembur suburban the north eastern corner of Mumbai about 15 $\mathrm{km}$ from Victoria Terminus (presently known as Chhatrapati Shivaji Terminus). The temperature of the area ranges between $13{ }^{\circ} \mathrm{C}$ to $39{ }^{\circ} \mathrm{C}$. The south west monsoon (June to mid-October) brings rain to the area which is recorded maximum $747 \mathrm{~mm}$ during July. The climate is humid and relative humidity ranges between 29 to $96 \%$ [34].

\section{2. Water sampling and sample preparation}

The study on pollution status along the Mahul creek of Mumbai was performed for the period of one year from January 2013 to December 2013. The sampling was done every month along different locations of the creek. The grab water samples were collected in polythene bottles of $2.5 \mathrm{~L}$. The bottles were thoroughly cleaned with hydrochloric acid, washed with distilled water to render free of acid, rinsed with the water sample to be collected and then filled with the sample leaving only a small air gap at the top. The sample bottles were stoppard and sealed using paraffin wax.

The samples thus collected were mixed to give gross sample. Such gross samples were analysed every month for the toxic heavy metal content, so as to get the seasonal variation in pollution level along the Mahul Creek. For estimation of dissolved heavy metal content in water, the collected sample was filtered using Whatman No. 41 filter paper. Filtrate was preserved with $2 \mathrm{~mL}$ nitric acid to prevent the precipitation of metals. The sample was concentrated to tenfold on a water bath and subjected to nitric acid digestion using the microwave assisted technique $[35,36]$.

\section{3. Analysis of Heavy Metals}

The water samples collected were analyzed for the heavy metal content. The analysis for the majority of the trace metals like lead $(\mathrm{Pb})$, copper $(\mathrm{Cu})$, zinc $(\mathrm{Zn})$, nickel $(\mathrm{Ni})$, cadmium $(C d)$ and chromium $(C r)$ in water samples was done by Flame Atomic Absorption spectrophotometer $(A A S)$ technique, while analysis of mercury $(H g)$ and Arsenic $(A s)$ was performed by cold-vapour and by hydride generation techniques coupled with an atomic fluorescence detector [37]. 
Table 1. Heavy Metals in Mahul Creek Water.

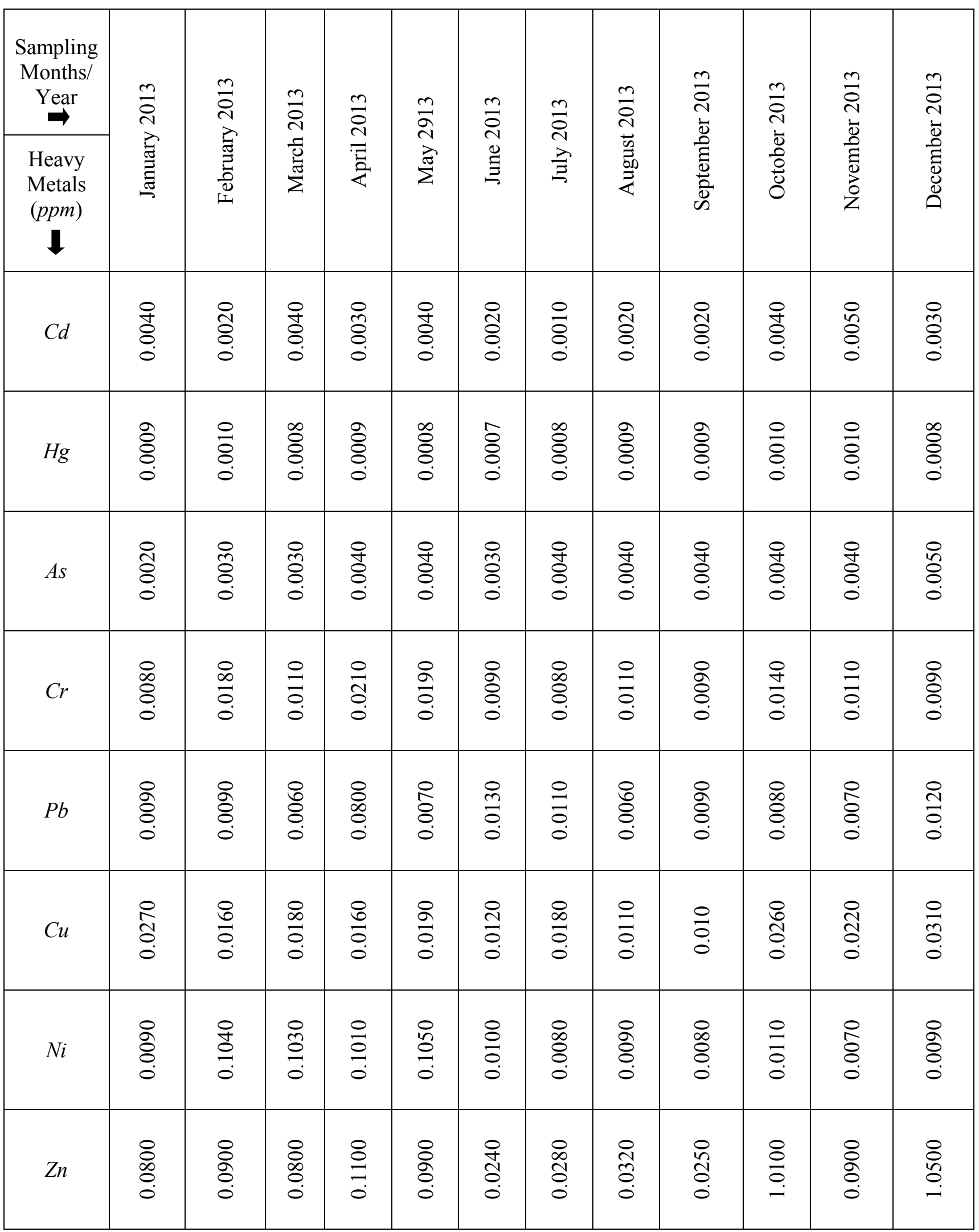




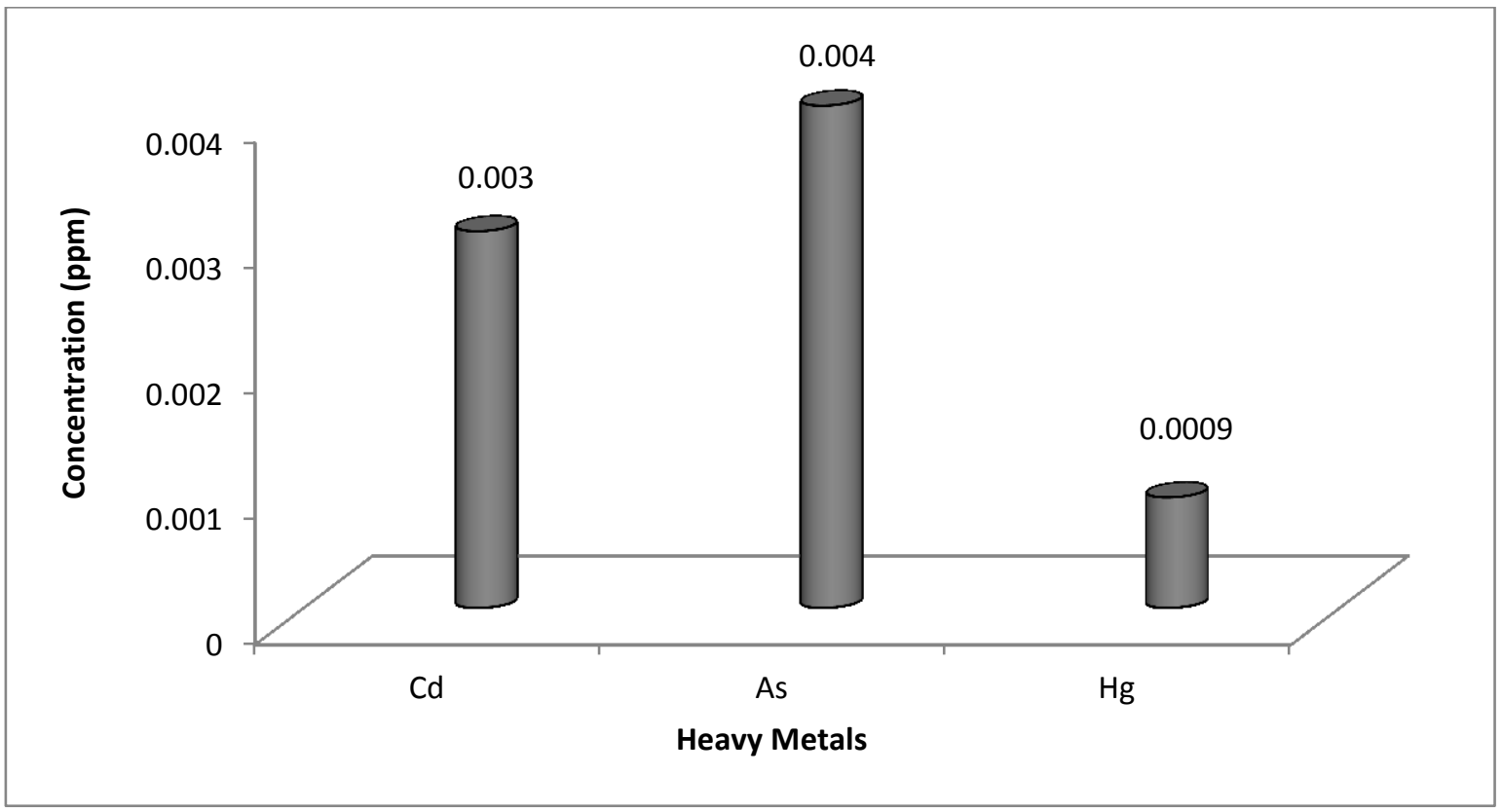

Figure 1. Annual average concentrations of Toxic heavy metals $(C d, A s$ and $H g$ ) in Mahul Creek water.

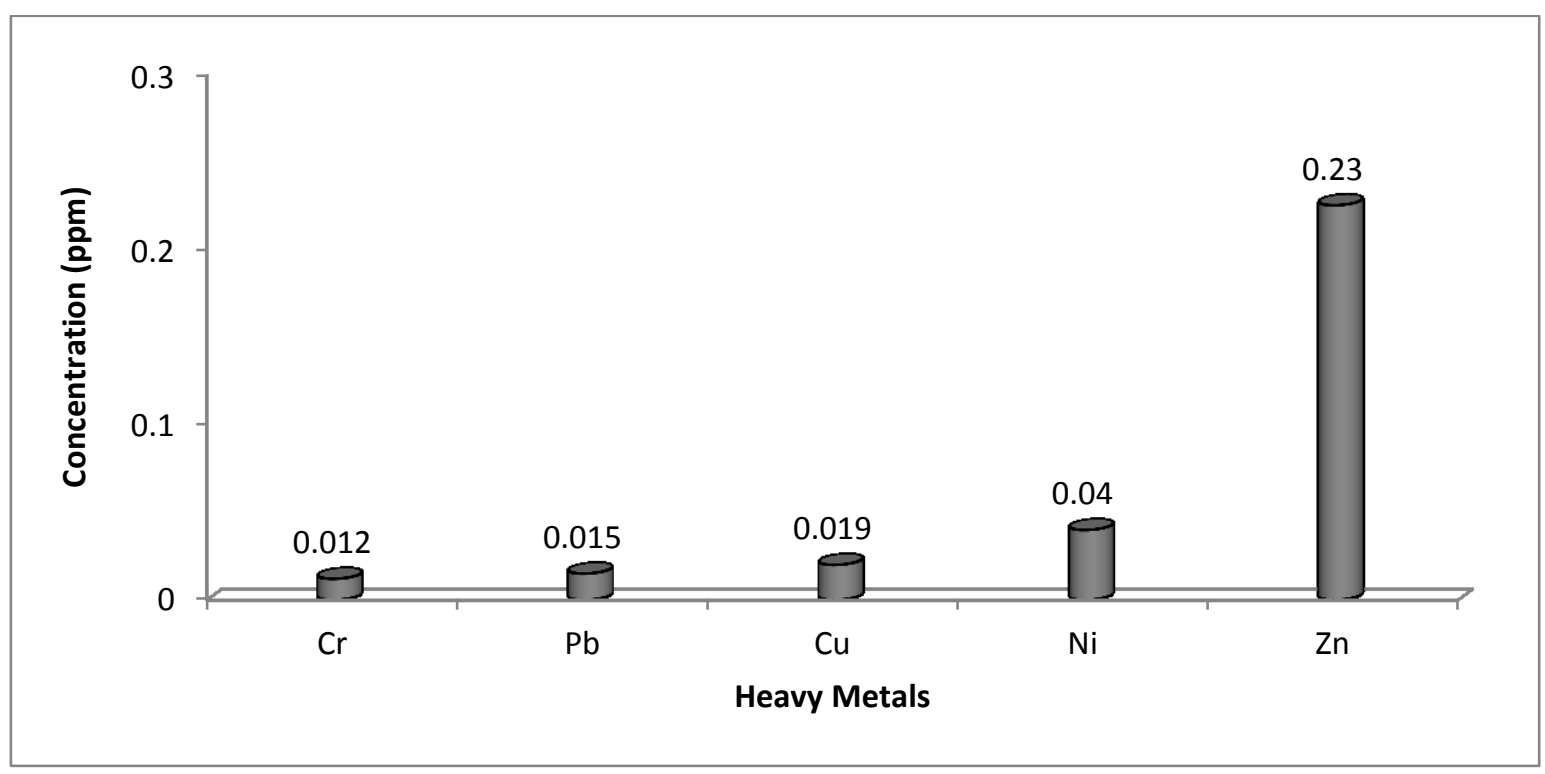

Figure 2. Annual average concentrations of Toxic heavy metals $(\mathrm{Cr}, \mathrm{Pb}, \mathrm{Cu}, \mathrm{Ni}$, and $\mathrm{Zn})$ in Mahul Creek water.

\section{RESULTS AND DISCUSSION}

Although there is no clear definition of what a heavy metal is, density is in most cases taken to be the defining factor. Heavy metals are thus generally defined as those having a specific density of more than $5 \mathrm{~g} / \mathrm{cm}^{3}$. Heavy metals are among the most common environmental pollutants, and their occurrence in waters and biota indicate the presence of natural or anthropogenic sources. Although adverse health effects of heavy metals have been 
known for a long time, discharge of heavy metals continues and is even increasing in some areas, in particular in less developed countries. The main threats to human health from heavy metals are associated with exposure to lead, cadmium, mercury and arsenic (arsenic is a metalloid, but is usually classified as a heavy metal). Their accumulation and distribution in soil and aquatic environment are increasing at an alarming rate thereby affecting marine life [38-40]. The experimental data on concentration ( $\mathrm{ppm}$ ) of toxic heavy metals like $\mathrm{Cr}, \mathrm{Pb}, \mathrm{Cu}$, $\mathrm{Ni}, \mathrm{Zn}, \mathrm{Cd}, \mathrm{As}$ and $\mathrm{Hg}$ in the water samples collected along the Mahul Creek of Mumbai is presented in Table 1. The annual average concentration of these metals is graphically represented in Figures 1 and 2.

The extensive studies [41-46] on ecological and toxicological aspects of lead $(\mathrm{Pb})$ and its compounds in the environment have revealed that $P b$ is neither essential nor beneficial to living organisms; all existing data show that its metabolic effects are adverse. It is toxic in most of its chemical forms and can be incorporated into the body by inhalation, ingestion, dermal absorption, and placental transfer to the foetus. It is an accumulative metabolic poison that affects behaviour, as well as the hematopoietic, vascular, nervous, renal, and reproductive systems. From the results of present investigation, it was observed that the concentration of $\mathrm{Pb}$ in the creek water was found to vary in the range of 0.006 to $0.08 \mathrm{ppm}$ with an annual average concentration of $0.015 \mathrm{ppm}$. $\mathrm{Cu}$ is highly toxic to most fishes, invertebrates and aquatic plants than any other heavy metal except mercury. It reduces growth and rate of reproduction in plants and animals. The chronic level of $\mathrm{Cu}$ is $0.02-0.2$ ppm [47]. Aquatic plants absorb three times more $C u$ than plants on dry lands [48]. Excessive $\mathrm{Cu}$ content can cause damage to roots, by attacking the cell membrane and destroying the normal membrane structure, inhibited root growth and formation of numerous short, brownish secondary roots [47]. Copper is highly toxic in aquatic environments and has effects in fish, invertebrates, and amphibians, with all three groups equally sensitive to chronic toxicity $[49,50]$. Copper will bio concentrate in many different organs in fish and mollusks. Copper also causes reduced sperm and egg production in many species of fish, such as fathead minnows, as well as early hatching of eggs, smaller fry (newly hatched fish) and increased incidence of abnormalities and reduced survival in the fry [51]. In the present study it was observed that the $C u$ concentration in the water samples was found to be minimum of $0.010 \mathrm{ppm}$ in the month of September and maximum of $0.031 \mathrm{ppm}$ in the month of December.

The annual average concentration of $C u$ was found to be $0.019 \mathrm{ppm}$. The concentration of $Z n$ in the creek water was found to vary in the range of 0.02 to $1.05 \mathrm{ppm}$ with an annual average concentration of $0.23 \mathrm{ppm}$. Nickel $(\mathrm{Ni})$ and nickel compounds have many industrial and commercial uses, and the progress of industrialization has led to increased emission of pollutants into ecosystems. The results of our study indicates that the concentration of $N i$ in the water was minimum of $0.01 \mathrm{ppm}$ in the month of November and $0.11 \mathrm{ppm}$ in the month of May, having annual average concentration of $0.04 \mathrm{ppm}$. Although $\mathrm{Ni}$ is omnipresent and is vital for the function of many organisms, concentrations in some areas from both anthropogenic release and naturally varying levels may be toxic to living organisms $[52,53]$. Nickel compounds have been well established as carcinogenic in many animal species and by many modes of human exposure but their underlying mechanisms are still not fully understood [54]. Cadmium $(C d)$ is typically a metal of the $20^{\text {th }}$ century, and is mainly used in rechargeable batteries and for the production of special alloys. It was the outbreak of the ItaiItai bone disease in Japan in the 1960s that really drew the attention of the public and regulatory bodies to this heavy metal that had been discharged in the environment at an uncontrolled rate for more than one century. From the results of our study it was observed that the $C d$ concentration in the creek water samples varies in the range of 0.001 to 0.005 $\mathrm{ppm}$ with an annual average concentration of $0.003 \mathrm{ppm}$. $\mathrm{Cd}$ dispersed in the environment can 
persist in soils and sediments for decades. When taken up by plants, $C d$ concentrates along the food chain and ultimately accumulates in the body of people eating contaminated foods. By far, the most salient toxicological property of $C d$ is its exceptionally long half-life in the human body. Once absorbed, $C d$ irreversibly accumulates in the human body, in particularly in kidneys, the bone, the respiratory tract and other vital organs such the lungs or the liver [55]. In addition to its extraordinary cumulative properties, $C d$ is also a highly toxic metal that can disrupt a number of biological systems, usually at doses that are much lower than most toxic metals [56-58]. Mercury $(\mathrm{Hg})$ poisoning has become a problem of current interest as a result of environmental pollution on a global scale.

High concentration of mercury, which could pose an ecological hazard, leading to contamination of plants, aquatic resources and bioaccumulation in the food chain [59]. In the present investigation it was observed that the concentration of $\mathrm{Hg}$ in the water was in the range of 0.0007 to $0.001 \mathrm{ppm}$ having the annual average concentration of $0.0009 \mathrm{ppm}$. Recently, the anthropogenic activities such as treatment of agricultural land with arsenical pesticides, treating of wood using chromated copper arsenate, burning of coal in thermal plants power stations and the operations of gold-mining have increased the environmental pervasiveness of $A s$ and its rate of discharge into freshwater habitat [60]. As can also interfere with the fish immune system by suppressing antibody production [61] as well as by lowering macrophage activity and maturation [62].

The results of our study indicates that $A s$ concentration in the creek water was lowest of $0.002 \mathrm{ppm}$ in the month of January and highest of $0.005 \mathrm{ppm}$ in the month of December with an annual average concentration of $0.004 \mathrm{ppm}$. Chromium $(\mathrm{Cr})$ is one of the most common skin sensitizers and often causes skin sensitizing effect in the general public. A possible source of chromium exposure is waste dumps for chromate-producing plants causing local air or water pollution. Penetration of the skin will cause painless erosive ulceration ("chrome holes") with delayed healing. These commonly occur on the fingers, knuckles, and forearms. The characteristic chrome sore begins as a papule, forming an ulcer with raised hard edges. Besides the lungs and intestinal tract, the liver and kidney are often target organs for chromate toxicity [63-69]. In the present investigation it was observed that the concentration of $\mathrm{Cr}$ in the water samples was in the range of 0.008 to $0.021 \mathrm{ppm}$ with an average concentration of $0.012 \mathrm{ppm}$.

\section{CONCLUSIONS}

Around the world as countries are struggling to arrive at an effective regulatory regime to control the discharge of industrial effluents into their ecosystems, Indian economy holds a double edged sword of economic growth and ecosystem collapse. As India progresses towards strict regulation of industrial effluents to control water pollution, greater efforts are required to reduce the risk to public health as colourless and odourless toxic pollutants are released into the ecosystems. Hence there is a need that each industry should treat their effluents, in accordance with the legal requirements, before discharging these into the streams otherwise 'Polluter pays' principle should be implemented. The current regulatory system in India for control of industrial discharges needs a complete improvement in terms of standards setting, monitoring and enforcement. The monitoring system for water quality needs to be strengthened both in terms of parameters monitored, water resources coverage and timely reporting to public domain. These steps are important in order to avoid irreparable ecological harm in the long term well masked by short term economic prosperity due to extensive industrial growth. 


\section{References}

1. I. Gupta, S. Dhage, A. A. Chandorkar, A. Srivastav, Environmental Modelling and Software, 19, 571 (2004).

2. P.U. Singare, R.S. Lokhande, A.G. Jagtap, International Journal of Global Environmental Issues, 11(1), 28-36 (2011).

3. P.U. Singare, R.S. Lokhande, A.G. Jagtap, Interdisciplinary Environmental Review, 11(4), 263-273 (2010).

4. R.S. Lokhande, P.U. Singare, D.S. Pimple, World Environment, 1(1), 6-13 (2011).

5. R.S. Lokhande, P.U. Singare, D.S. Pimple, Resources and Environment, 1(1):13-19(2011)

6. R.S. Lokhande, P.U. Singare, D.S. Pimple, International Journal of Ecosystem, 1(1), 1-9 (2011).

7. S.K. Sasamal, K.H. Rao, U.M. Suryavansi, International J. Remote Sensing, 28(19), 43914395 (2007).

8. A. Nagaraju, S. Suresh, K. Killham, K. Hudson-Edward, Turkish J. Eng. Env. Sci., 30(4), 203-219 (2006).

9. T. Rajaram, A. Das, Futures, 40, 56 (2008).

10. M.D. Zingade, M.M. Sabnis, A.V. Mandalia, B.N. Desai, Mahasagar Bull. Natn. Inst. Occeonagr., 13, 99 (1980).

11. P.U. Singare, S.S.Dhabarde, International Letters of Chemistry, Physics and Astronomy, 3 (2014) 56-63..

12. P.U. Singare, S.S. Dhabarde, International Letters of Chemistry, Physics and Astronomy, 3 (2014) 48-55.

13. P.U. Singare, S.S. Dhabarde, International Letters of Chemistry, Physics and Astronomy, 3 (2014) 40-47.

14. P.U. Singare, S.S. Dhabarde, International Letters of Chemistry, Physics and Astronomy, 3 (2014) 32-39.

15. P.U. Singare, S.S. Dhabarde, International Letters of Chemistry, Physics and Astronomy, 3 (2014) 8-15.

16. P.U. Singare, S.S. Dhabarde, International Letters of Chemistry, Physics and Astronomy, 3 (2014) 16-23.

17. P.U. Singare, S.S. Dhabarde, International Letters of Chemistry, Physics and Astronomy, 3 (2014) 24-31.

18. S. K. Sasamal, K. H. Rao, U. M. Suryavansi, International J. Remote Sensing, 28, 4391 (2007).

19. S.K. Jha, T.M. Krishnamoorthy, G.G. Pandit, K.S.V. Nambi, Science of the total Environment, 236, 91 (1999).

20. S.K. Sahu, P.Y. Ajmal, G.G. Pandit, V.D. Puranik, Journal of Hazardous Materials, 164, 1573 (2009).

21. S. K. Jha, S. B. Chavan, G. G. Pandit, B. S. Negi, S. Sadasivan, Environmental Monitoring and Assessment, 76, 249 (2002). 
22. P.U. Singare, R.S. Lokhande, K.U. Naik, Interdisciplinary Environmental Review, 11, 90 (2010).

23. P.U. Singare, R.S. Lokhande, P.P. Pathak, J. Environmental Protection, 1, 121 (2010).

24. P.U. Singare, R.S. Lokhande, P.P. Pathak, Interdisciplinary Environmental Review, 11, 38 (2010).

25. R.S. Lokhande, N. Kelkar, Indian J. Environ. Protect., 19, 664 (1999).

26. M.D. Zingde, K. Govindan, Health status of coastal waters of Mumbai and regions around. In: Environmental Problems of Coastal Areas in India (ed. V.K. Sharma), Bookwell Publishers., New Delhi, pp. 119-132 (2001).

27. P.U. Singare, M.S. Talpade, D.V. Dagli, V.G. Bhawe, International Letters of Chemistry, Physics and Astronomy, 8(2), 105-112 (2013).

28. P.U. Singare, M.S. Talpade, Interdisciplinary Environmental Review, 14(1), 59-68 (2013).

29. M.C. Kennicutt, T.L. Wade, B.J. Presley, A.G. Requejo, J.M. Brooks, G.J. Denoux, Environ. Sci. Technol., 28, 1 (1993).

30. W.J. Adams, R.A. Kimerle, J.W.Barnett Jr., Environ Sci Technol., 26, 1864 (1992).

31. R. K. Sharma, M. Agrawal, F.M. Marshall, 'Effects of waste water irrigation on heavy metal accumulation in soil and plants', Paper presented at a National Seminar, Bangalore University, Bangalore, Abst. no. 7, pp. 8 (2004).

32. D.P. Weston, K.A. Maraya, Environ. Toxicol. Chem., 21, 962 (2002).

33. A. Kumar, Pol. Arch. Hydrobiol., 18, 469 (1996).

34. A. Verma, S. Balachandran, N. Chaturvedi, V. Patil, Zoos' Print Journal, 19(9), 15991605 (2004).

35. L.S. Clesceri, Standard methods for the examination of water and waste water. In Collection and Preservation of Samples and Metals (eds. E. Arnold, Greenbergy, A.D. Eaton), APHA, AWWA, WEF, Washington, DC, pp. 1-27-1-35; 3-1-3-21, (1998).

36. A. Paar, Microwave Sample Preparation System - Instruction Handbook, Anton Paar GmbH, Austria, pp. 128, (1998).

37. G.H. Jeffery, J. Bassett, J. Mendham, R.C. Denny, Vogel's Textbook of Quantitative Chemical Analysis, Longman Scientific \& Technical, England, $5^{\text {th }}$ Edition, pp.87, 788 (1989).

38. B. Koukal, J. Dominik, D. Vignati, P. Arpagaus, S. Santiago, B. Ouddane, L. Benaabidate, Environ. Poll., 131 (1), 163-172 (2004).

39. K.M. Mohiuddin, H.M. Zakir, K. Otomo, S. Sharmin, N. Shikazono, Int. J. Environ. Sci. Tech., 7 (1), 17-28(2010).

40. E.C. Okafor, K. Opuene, Int. J. Environ. Sci. Tech., 4 (2) 233-240 (2007).

41. EPA. Ambient water quality criteria for lead - 1984. U.S. Environ. Protection Agency Rep. 440/5-84-027. pp.81 Available from Natl. Tech. Infor. Serv., 5285 Port Royal Road, Springfield, Virginia 22161 (1985).

42. J.S. Feierabend, A.B. Russell, (eds.), Lead poisoning in wild waterfowl - a workshop. National Wildlife Federation, 1412 Sixteenth St. NW, Washington, D.C. pp.139 (1986). 
43. FWS. Use of lead shot for hunting migratory birds in the United States. Final supplemental environmental impact statement. pp.535 Available from U.S. Fish Wildlife Service, Office of Migratory Bird Management, Washington, D.C. 20240 (1986).

44. R. Lansdown, W. Yule (eds.), Lead toxicity. History and environmental impact, Johns Hopkins Univ. Press, Baltimore, Maryland. pp.286 (1986).

45. L.J. McDonald, Can. Vet. J., 27(3), 131-134 (1986).

46. G.C. Sanderson, F.C. Bellrose, Illinois Natural History Survey, Spec. Publ. (SP-04). 1-34 (1986).

47. N.S. Tiwana, N. Jerath, G. Singh, M. Ravleen (Eds.), Heavy metal pollution in Punjab Rivers, in Newsletter Environmental Information System (ENVIS), Punjab State Council for Science and Technology, India, 3(1) (2005).

48. Centre for Ecological Sciences., IISc Environmental Hand Book-Documentation on Monitoring and Evaluating Environmental Impacts, of Environmental Standards, Vol.3, Indian Institute of Science, Bangalore (2001).

Available at http://wgbis.ces.iisc.ernet.in/energy/HC270799/HDL/ENV/START.HTM (Accessed on 01 March 2010).

49. US EPA. Wildlife Exposure Factor Handbook. Vol. 1 EPA/600/R-93/187a (1993).

50. M.T. Horne, W.A. Dunson, Archives of Environmental Contamination and Toxicology 29(4), 500-505 (1995).

51. B. Taub Frieda, Fish 430 lectures (Biological Impacts of Pollutants on Aquatic Organisms), University of Washington College of Ocean and Fishery Sciences, Seattle, WA (2004).

52. L.T. Haber, L. Erdreicht, G.L. Diamond, A.M. Maier, R. Ratney, Q. Zhao, M. Dourson, Regul. Toxicol. Pharmacol., 31(2), 210-230 (2000).

53. V. Diagomanolin, M. Farhang, M. Ghazi-Khansari, N. Jafarzadeh, Iran, Toxicol. Lett., 151(1), 63 (2004).

54. F.W. Sunderman, (JR.), S.M. Hopfer, M.C. Plowman, J.A Knight, Res. Commun. Chem. Pathol. Pharmacol., 70(1), 103 (1990).

55. N. Johri, G. Jacquillet, R. Unwin, BioMetals, 23(5), 783-792 (2010).

56. G. Nordberg, K. Nogawa, M. Nordberg, L. Friberg, Cadmium. In: Handbook on toxicology of metals. Nordberg, G., Fowler, B., Nordberg, M., Friberg, L. editors New York: Academic Press, p. 65-78 (2007).

57. A. Bernard, Biometals, 17(5), 519-523 (2004).

58. J. Godt, F. Scheidig, C.G. Siestrup, V. Esche, P. Brandenburg, A. Reich, D.A. Groneberg, J. Occup. Med. Toxicol., 1, 22 (2006).

59. L. Favretto, B. Campisi, E. Reisenhofer, G. Adami, Anal. Chim. Acta, 344(3), 251-259 (1997).

60. J.M. Pacyna, M.T.Scholtz, Y.F. Li, Environ. Rev., 3(2), 145-159 (1995).

61. D. Gosh, S. Datta, S. Bhattacharya, S. Mazumder, Aquat. Toxicol., 81(1), 79-89 (2007).

62. D. Gosh, S. Datta, S. Bhattacharya, S. Mazumder, Comp. Biochem. Physiol., 143C: 455463 (2006). 
63. W.N. Rom, Environmental and Occupational Medicine. $4^{\text {th }}$ Ed. by Lippincott Williams $\&$ Wilkins (2007).

64. Omprakash Sahu, International Letters of Natural Sciences 7 (2014) 35-43.

65. Piotr Daniszewski, Ryszard Konieczny, International Letters of Chemistry, Physics and Astronomy 4 (2013) 91-97.

66. Piotr Daniszewski, Ryszard Konieczny, International Letters of Chemistry, Physics and Astronomy 4 (2013) 98-104.

67. Piotr Daniszewski, International Letters of Chemistry, Physics and Astronomy 4 (2012) 119-124.

68. Emil Cyraniak, Piotr Daniszewski, Beata Draszawka-Bołzan, International Letters of Chemistry, Physics and Astronomy 5 (2012) 88-95.

69. Emil Cyraniak, Piotr Daniszewski, Beata Draszawka-Bołzan, International Letters of Chemistry, Physics and Astronomy 5 (2012) 96-103. 